Article

\title{
Evolution of Deformation Fabrics Related to Petrogenesis of Upper Mantle Xenoliths Beneath the Baekdusan Volcano
}

 \\ 1 Tectonophysics Laboratory, School of Earth and Environmental Sciences, Seoul National University, \\ Seoul 08826, Korea; munjaepark@korea.ac.kr (M.P.); hjung@snu.ac.kr (H.J.) \\ 2 Department of Earth and Environmental Sciences, Korea University, Seoul 02841, Korea \\ 3 Department of Energy and Resources Engineering, Chonnam National University, Gwangju 61186, Korea \\ * Correspondence: ykil@jnu.ac.kr; Tel.: +82-62-530-1731
}

Received: 31 July 2020; Accepted: 20 September 2020; Published: 21 September 2020

\begin{abstract}
Knowledge of the formation and evolution of cratonic subcontinental lithospheric mantle is critical to our understanding of the processes responsible for continental development. Here, we report the deformation microstructures and lattice preferred orientations (LPOs) of olivine and pyroxenes alongside petrological data from spinel peridotite xenoliths beneath the Baekdusan volcano. We have used these datasets to constrain the evolution of deformation fabrics related to petrogenesis from the Baekdusan peridotites. Based on petrographic features and deformation microstructures, we have identified two textural categories for these peridotites: coarse- and fine-granular harzburgites (CG and FG Hzb). We found that mineral composition, equilibrium temperature, olivine LPO, stress, and extraction depth vary considerably with the texture. We suggest that the A-type olivine LPO in the CG Hzb may be related to the preexisting Archean cratonic mantle fabric (i.e., old frozen LPO) formed under high-temperature, low-stress, and dry conditions. Conversely, we suggest that the D-type olivine LPOs in the FG Hzb samples likely originated from later localized deformation events under low-temperature, high-stress, and dry conditions after a high degree of partial melting. Moreover, we consider the Baekdusan peridotite xenoliths to have been derived from a compositionally and texturally heterogeneous vertical mantle section beneath the Baekdusan volcano.
\end{abstract}

Keywords: spinel peridotite xenoliths; deformation microstructures; lattice preferred orientation; petrogenesis; mantle heterogeneity; Baekdusan volcano

\section{Introduction}

Cratons are the oldest and thickest domains of the Earth's lithosphere [1,2] and are commonly associated with subcontinental lithospheric mantle (SCLM), which is characterized by a cold lithospheric mantle root extending to depths $>250 \mathrm{~km}$ [3]. Knowledge of the formation and evolution of SCLM is critical to our understanding of the processes responsible for continental development [4]. Cratonic SCLM typically comprises of highly refractory residues produced by high degrees of partial melting [5-8]. This refractory mantle is unlikely to melt again subsequently unless heated by a hot mantle plume [2] because the cratonic lithosphere is relatively cold and rigid. However, some cratons, such as the North China Craton (NCC), did not remain stable following their formation; this kind of craton is characterized by extensive ductile deformation of deep crustal rocks and an abundance of crust-derived felsic magmatism [2].

Fragments of deep cratonic lithosphere, such as peridotite xenoliths, can be brought to the surface by basaltic magmas. These xenoliths can provide valuable insights into deformation processes in the upper mantle $[9,10]$; thus, enhancing our understanding of physical and chemical characteristics 
and deformation conditions in the upper mantle [11-13]. Previous experimental studies considering deformation fabrics have focused on the lattice-preferred orientations (LPOs) of olivine at high pressures and temperatures and have demonstrated that the LPOs of olivine can be controlled significantly by water and stress [14-16], temperature [17], and pressure [18-20]. The Baekdusan (also called as Changbaishan in China) volcano is a prominent active volcano located on the border between China and North Korea. To date, few petrological and geochemical studies have been undertaken to investigate peridotite xenoliths hosted in basaltic rocks associated with this volcano [21,22]. Accordingly, the physicochemical heterogeneity of cratonic mantle in this region, and its relationship to local deformation fabrics and petrological characteristics (i.e., modal and chemical compositions), remains poorly constrained. Moreover, the detailed microstructures of the deformed peridotites beneath Baekdusan have not yet been reported in the literature. To address these gaps in knowledge, we have studied spinel peridotite xenoliths beneath the Baekdusan volcano. Here, we report our results and discuss their significance for constraining the evolution of deformation fabrics produced in olivine and pyroxenes in relation to petrogenesis in the cratonic mantle.

\section{Geological Background and Sampling}

The Chinese portion of the Sino-Korean craton is known as the NCC and is one of the oldest cratonic blocks globally [2]; it contains Eoarchean rocks with ages up to 3.8 Ga [25,26]. Previously, the NCC has been divided into eastern and western blocks and the intervening Trans-North China Orogen based on its age, lithological assemblages, and tectonic evolution [27]. The Archean basement of the eastern NCC is composed primarily of the following: tonalite-trondhjemite-granodiorite (TTG) gneisses (2.6-2.5 Ga); mafic to ultramafic igneous rocks and syntectonic granites ( 2.5 Ga); and a variety of supracrustal rocks $[27,28]$. The NCC remained stable from its amalgamation $(\sim 1.85 \mathrm{Ga})$ until the initiation of massive circum-craton Phanerozoic subduction and collisional orogenies [3]. However, the eastern part of the NCC experienced widespread tectonothermal reactivation during the Phanerozoic subduction, as revealed by the presence of voluminous Late Mesozoic mafic and felsic igneous rocks and extensive Tertiary alkali basaltic volcanism [29-31].

The Baekdusan volcanic field is located along the northeastern margin of the NCC (Figure 1). Moreover, it is located far away from the Japanese subduction zone (ca. $900 \mathrm{~km}$ ) (Figure 1), indicating that volcanism here is of intraplate origin [32]. However, recent seismotomographic studies have suggested the presence of a stagnant slab in the mantle transition zone and the possible presence of a hydrous mantle upwelling beneath Baekdusan [33-35]; this may have produced subduction-induced hydrous mantle upwelling. The Baekdusan volcano consists of an early-stage basaltic plateau, a middle-stage trachytic cone, and a late-stage explosive comenditic ignimbrite [36,37]. Previous studies have shown that the main early shield-forming eruptions and cone construction occurred $\sim 22.6$ to $1.5 \mathrm{Ma}$ and between $\sim 1.0 \mathrm{Ma}$ and $20 \mathrm{ka}$, respectively, followed by Quaternary volcanic events including the Millennium eruption [36,38]. We collected peridotite xenoliths hosted in massive basaltic rocks from the northern part $\left(42^{\circ} 12^{\prime} 30.98^{\prime \prime} \mathrm{N}, 128^{\circ} 11^{\prime} 41.70^{\prime \prime} \mathrm{E}\right)$ of the Baekdusan volcano. 


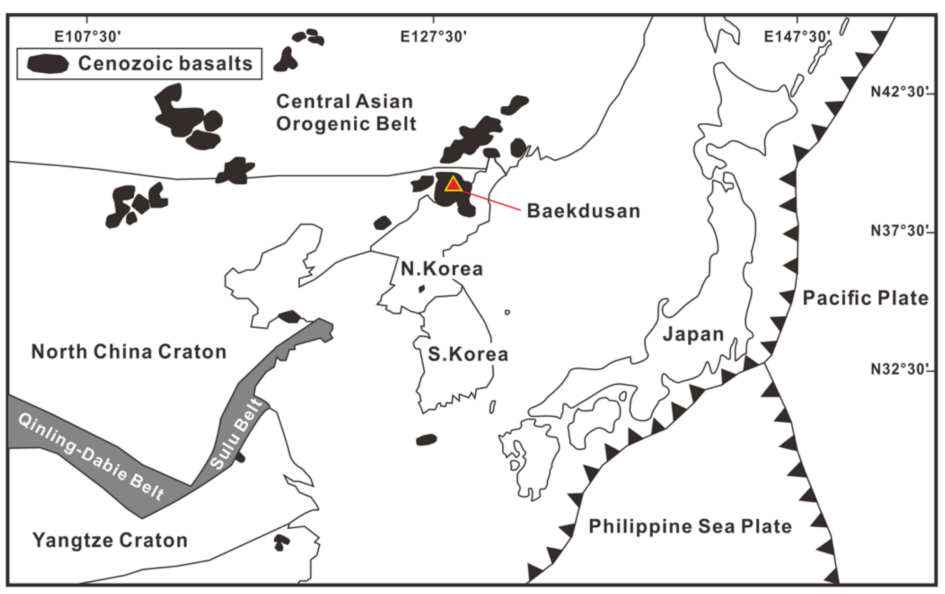

Figure 1. Simplified geologic map of the Baekdusan area showing the distribution of Cenozoic intraplate basalts in northeastern China and Korea (modified from $[21,23,24]$ ) and the sampled location at Baekdusan.

\section{Methods}

\subsection{Mineral Chemistry}

The major element compositions of target minerals (olivine, orthopyroxene, clinopyroxene, and spinel) were determined using a field emission electron probe microanalyzer (FE-EPMA; JEOL JXA-8530F) at the Korea Polar Research Institute. The accelerating voltage, beam current, beam diameter, and counting time were $15 \mathrm{kV}, 10 \mathrm{nA}, 3 \mu \mathrm{m}$, and $20 \mathrm{~s}$, respectively. The detection limits $(3 \sigma)$ in wt $\%$ are as follows: 0.01 for $\mathrm{CaO}$ and $\mathrm{K}_{2} \mathrm{O}, 0.02$ for $\mathrm{MgO}$ and $\mathrm{Na}_{2} \mathrm{O}, 0.03$ for $\mathrm{SiO}_{2}, \mathrm{TiO}_{2}, \mathrm{Al}_{2} \mathrm{O}_{3}$, and $\mathrm{Cr}_{2} \mathrm{O}_{3}$, and 0.04 for $\mathrm{FeO}$ and $\mathrm{MnO}$. Three to four grains were measured for each mineral and we represent here averages. There was no clear distinction in element concentrations between the cores and rims of the constituent minerals. Based on the obtained mineral compositions, we calculated equilibrium temperatures using the two-pyroxene thermometer by Brey and Köhler [39].

\subsection{Measurement of LPO}

For petrographic and microstructural observations, the foliation and lineation of rock samples were determined by observing the compositional layering and alignment of olivine, pyroxenes, and spinel grains. Rock sections were cut parallel to the $X Z$ plane of the $X Y Z$ structural reference frame (where $X Y$ represents the macroscopic foliation and the $X$ direction represents the direction of the stretching lineation), and thin sections were produced for electron backscatter diffraction (EBSD) analysis according to previously published methods [40,41]. The LPOs of the minerals were measured using an automated EBSD system and a symmetry detector (Oxford Instruments, Abingdon, UK) attached to a field emission scanning electron microscope (FE-SEM; JEOL JSM-7100F) at the School of Earth and Environmental Sciences at Seoul National University. The working parameters for the EBSD analysis included accelerating voltage, working distance, and stage tilt of $15.0 \mathrm{kV}, 25.0 \mathrm{~mm}$, and $70^{\circ}$ from the horizontal, respectively. Kikuchi diffraction patterns were obtained automatically using the Aztec software (Oxford Instruments HKL) with a sampling step size of $25 \mu \mathrm{m}$; this is significantly smaller than the average grain size of the constituent minerals. The HKL CHANNEL 5 software was used to process the EBSD data as described in previous studies [40,41]. To avoid oversampling of large grains and to permit comparison of fabrics between samples, pole figures were constructed from one point per grain $[40,41]$. Contoured pole figures for each mineral were plotted using lower-hemisphere equal-area stereographic projection. Fabric strength of the LPOs was quantified using the M-index [42]. The LPOs of clinopyroxenes obtained here were compared with the conventional LPO of clinopyroxene, where the [001] axes are commonly aligned subparallel to the lineation and the (010) planes are aligned subparallel to the foliation in naturally deformed rocks $[43,44]$. 


\section{Results}

\subsection{Petrographic Features and Deformation Microstructures}

We found the spinel harzburgite xenoliths from Baekdusan to consist of olivine (63-75 vol.\%), orthopyroxene (21-34 vol.\%), clinopyroxene (up to 5 vol.\%), and minor spinel (up to 0.6 vol.\%), based on the area fraction of each mineral in the EBSD maps (Table 1). Generally, we found all peridotite xenoliths to exhibit weak foliation. We identified two main textural categories of peridotites based on petrographic features (including grain size): coarse-granular and fine-granular (Table 1).

Table 1. Summarized results of the studied peridotite xenoliths from Baekdusan.

\begin{tabular}{|c|c|c|c|c|c|c|c|c|c|c|c|}
\hline \multirow[t]{2}{*}{ Sample } & \multirow[t]{2}{*}{ Rock } & \multirow[t]{2}{*}{ Texture } & \multicolumn{4}{|c|}{ Modal Composition ${ }^{1}(\%)$} & \multirow{2}{*}{$\begin{array}{c}\mathrm{T}^{2} \\
\left({ }^{\circ} \mathrm{C}\right)\end{array}$} & \multirow{2}{*}{$\begin{array}{l}G S^{3} \\
(\mu \mathrm{m})\end{array}$} & \multirow{2}{*}{$\begin{array}{c}\text { Stress }^{4} \\
\text { (MPa) }\end{array}$} & \multicolumn{2}{|c|}{ Olivine LPO } \\
\hline & & & Ol & Opx & Cpx & Sp & & & & LPO & $\mathbf{M}^{5}$ \\
\hline BD-19 & $\mathrm{Hzb}$ & $\mathrm{CG}$ & 71.0 & 23.4 & 5.0 & 0.6 & 992 & $864 \pm 86$ & 9 & A-type & 0.24 \\
\hline BD-17 & $\mathrm{Hzb}$ & FG & 62.0 & 33.7 & 4.0 & 0.3 & 855 & $384 \pm 52$ & 16 & D-type & 0.23 \\
\hline BD-21 & $\mathrm{Hzb}$ & FG & 74.8 & 21.0 & 4.0 & 0.3 & 845 & $452 \pm 45$ & 14 & D-type & 0.22 \\
\hline
\end{tabular}

$\mathrm{Hzb}$ (harzburgite), CG and FG (coarse- and fine-granular), Ol (olivine), Opx (orthopyroxene), Cpx (clinopyroxene), and Sp (spinel). ${ }^{1}$ Based on the area fraction of each mineral in the EBSD maps. ${ }^{2}$ Equilibrium temperature was calculated by the two-pyroxene thermometer [39] at $15 \mathrm{kbar}$, st. dev. $\pm 16{ }^{\circ} \mathrm{C} .{ }^{3}$ Grain-size (GS) of olivine was estimated by EBSD mapping analysis. ${ }^{4}$ Stress was estimated using recrystallized grain size piezometer [45], st. dev. $\pm 1 \mathrm{MPa} .{ }^{5} \mathrm{M}$-index (M): the misorientation index which shows the fabric strength of olivine [42].

The coarse-granular peridotite (BD-19) is characterized by large grains (2-8 $\mathrm{mm}$ ) with abundant $120^{\circ}$ triple junctions at grain boundaries (Figure 2a,b). It represents roughly a protogranular texture. The mean grain size of olivine grains in this peridotite is approximately $860 \mu \mathrm{m}$ (Table 1) and olivine grains in the sample typically exhibit subgrains and undulose extinction (Figure 3b).

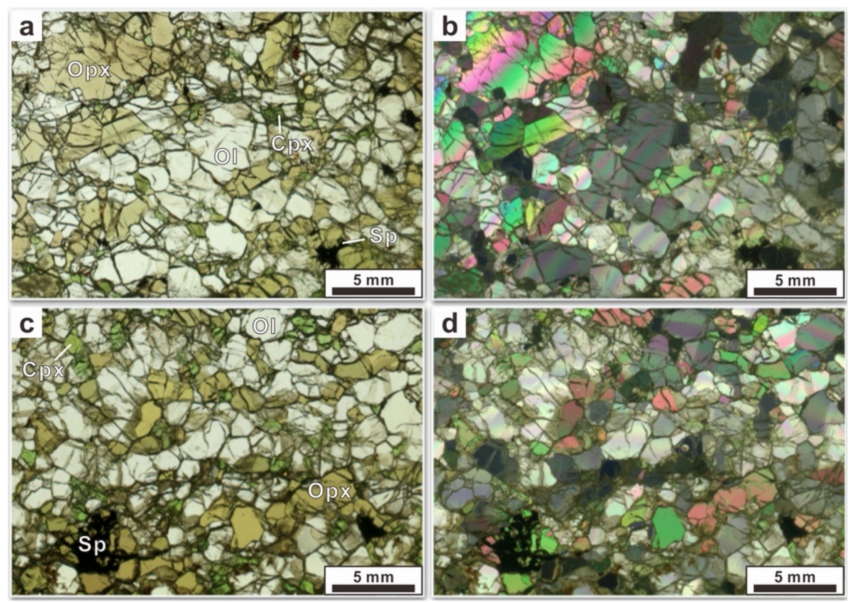

Figure 2. Optical photomicrographs of large-scale thin sections in plane-polarized light (a,c) and cross-polarized light $(\mathbf{b}, \mathbf{d})$ illustrating the typical microstructures from the Baekdusan peridotite xenoliths. (a,b) Coarse-granular peridotite (BD-19). (c,d) Fine-granular peridotite (BD-17). Ol (olivine), Opx (orthopyroxene), Cpx (clinopyroxene), and Sp (spinel).

The fine-granular peridotites (BD-17 and BD-21) are characterized by relatively small grains (1-3 mm) with equigranular textures (Figure $2 \mathrm{c}, \mathrm{d}$ ). We commonly observed $120^{\circ}$ triple junctions at grain boundaries in these samples, indicating a well-equilibrated microstructure. The mean grain sizes of olivine crystals in BD-17 and BD-21 were approximately $380 \mu \mathrm{m}$ and $450 \mu \mathrm{m}$ (Table 1), respectively. We found subgrains and undulose extinctions to be more common in these olivine grains than in the coarse-granular sample (Figure 3d,f). 


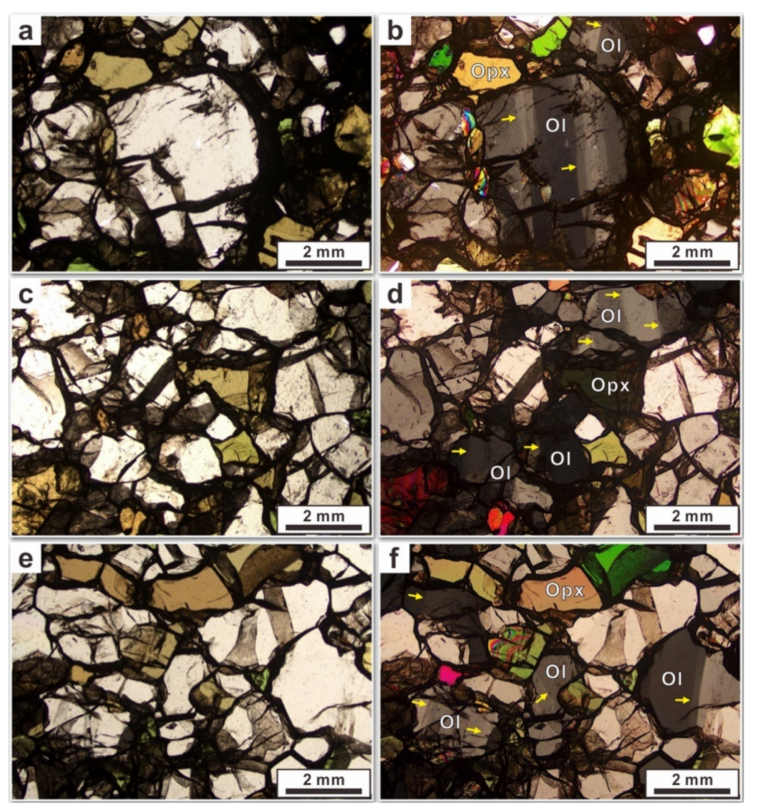

Figure 3. Optical photomicrographs of small-scale thin sections in plane-polarized light (a,c,e) and cross-polarized light $(\mathbf{b}, \mathbf{d}, \mathbf{f})$ illustrating the typical microstructures from the Baekdusan peridotite xenoliths. (a,b) Coarse-granular peridotite (BD-19). (c,d) Fine-granular peridotite (BD-17). (e,f) Fine-granular peridotite (BD-21). Ol (olivine), Opx (orthopyroxene). Yellow arrows denote subgrain boundaries and/or undulose extinction in olivine.

Both the coarse- and fine-granular peridotites typically display straight and gently curved grain boundary morphologies (Figures 2 and 3). Orthopyroxenes typically exhibit clinopyroxene exsolution lamellae, whereas clinopyroxenes have orthopyroxene lamellae or exsolved spinel blobs. Clinopyroxene is present only as small lobate forms in the matrix (Figure 2a,c), often with spongy rims. Spinels are present as small and anhedral grains forming intergrowths with orthopyroxene or as interstitial grains with amoeboid shapes (Figure 2a,c).

\subsection{Mineral Compositions and Equilibrium Temperatures}

The mineral compositions of spinel peridotite xenoliths from Baekdusan are presented in Table 2. We found the olivine Fo contents to be similar in the coarse- and fine-granular peridotites (90.7-91.1) and found no clear distinction in element concentrations between the cores and rims of the olivine crystals. The orthopyroxenes are enstatite-rich, with $\mathrm{Mg} \#[=100 \mathrm{Mg} /(\mathrm{Mg}+\mathrm{Fe})]$ of 90.6 and $91.1-91.4$ in


coarse-granular peridotite (3.92 $\mathrm{wt} \%$ ) are slightly higher than those in the fine-granular peridotites (2.63-2.65 wt\%). Similarly, we found the $\mathrm{Cr}_{2} \mathrm{O}_{3}$ contents of orthopyroxenes to be $0.60 \mathrm{wt} \%$ and $0.47 \mathrm{wt} \%$ in the coarse- and fine-granular peridotites, respectively. The $\mathrm{Cr} \#[=100 \mathrm{Cr} /(\mathrm{Cr}+\mathrm{Al})]$ of orthopyroxenes is 9.2 and 10.6-10.8 in the coarse-and fine-granular peridotites, respectively. For clinopyroxenes, we found $\mathrm{Mg} \#$ to be 91.3 and 93.5-93.7 in the coarse- and fine-granular peridotites, respectively. The $\mathrm{Al}_{2} \mathrm{O}_{3}$ contents of clinopyroxenes in the coarse-granular peridotite $(4.09 \mathrm{wt} \%)$ are also slightly higher than those in the fine-granular peridotites (2.71-2.72 wt\%). The Mg\# and $\mathrm{Cr} \#$ of pyroxenes in the fine-granular peridotites are higher than those in the coarse-granular peridotite (Table 2 and Figure 4). For spinels, we found a clear distinction in $\mathrm{Al}_{2} \mathrm{O}_{3}$ and $\mathrm{Cr}_{2} \mathrm{O}_{3}$ contents between coarse- and fine-granular peridotites. In particular, we found spinels in fine-granular peridotites to be characterized by much higher $\mathrm{Cr} \#$ (37.6-38.3) and lower Mg\# (66.4-66.5) than those in the coarse-granular peridotite, for which we found $\mathrm{Cr} \#$ and $\mathrm{Mg \#}$ to be 24.1 and 73.3, respectively. Spinel Mg\# exhibits a negative correlation with spinel Cr\# (Figure 4a), whereas spinel Cr\# exhibits a positive correlation with olivine Fo content (Figure 4b). Based on the spinel Cr\# versus Mg\# relationship and the relationship between 
olivine Fo\# and spinel Cr\#, the Baekdusan peridotites plot between abyssal and suprasubduction zone (SSZ) peridotites (Figure 4). This is broadly consistent with a previous geochemical study [21], in which the olivine and spinel compositions of Baekdusan harzburgites extended toward more fertile (SSZ) compositions.

Table 2. Compositions of minerals of studied peridotite xenoliths from Baekdusan.

\begin{tabular}{|c|c|c|c|c|c|c|c|c|c|c|c|c|}
\hline Sample & \multicolumn{4}{|c|}{ BD-19 } & \multicolumn{4}{|c|}{ BD-17 } & \multicolumn{4}{|c|}{ BD-21 } \\
\hline Rock & \multicolumn{4}{|c|}{ Harzburgite } & \multicolumn{4}{|c|}{ Harzburgite } & \multicolumn{4}{|c|}{ Harzburgite } \\
\hline Texture & \multicolumn{4}{|c|}{ Coarse-Granular } & \multicolumn{4}{|c|}{ Fine-Granular } & \multicolumn{4}{|c|}{ Fine-Granular } \\
\hline Mineral & O1 & Opx & Cpx & $S p$ & Ol & Opx & Cpx & $\mathrm{Sp}$ & Ol & Opx & Cpx & Sp \\
\hline $\begin{array}{c}\mathrm{SiO}_{2} \\
(\mathrm{wt} \%)\end{array}$ & 41.26 & 55.09 & 52.60 & - & 41.20 & 56.65 & 53.69 & - & 40.75 & 56.11 & 53.53 & - \\
\hline $\mathrm{TiO}_{2}$ & - & 0.04 & 0.09 & 0.10 & - & 0.04 & 0.11 & 0.06 & - & - & 0.08 & 0.09 \\
\hline $\mathrm{Al}_{2} \mathrm{O}_{3}$ & - & 3.92 & 4.09 & 46.56 & - & 2.63 & 2.71 & 35.53 & - & 2.65 & 2.72 & 35.90 \\
\hline $\mathrm{Cr}_{2} \mathrm{O}_{3}$ & - & 0.60 & 0.81 & 21.98 & - & 0.47 & 0.82 & 32.91 & - & 0.47 & 0.87 & 32.22 \\
\hline $\mathrm{FeO}^{*}$ & 8.73 & 6.08 & 2.88 & 12.13 & 9.02 & 5.87 & 2.13 & 14.48 & 8.99 & 5.69 & 2.03 & 14.69 \\
\hline $\mathrm{MnO}$ & 0.10 & 0.21 & 0.12 & 0.21 & 0.09 & 0.16 & 0.06 & 0.22 & 0.15 & 0.11 & 0.03 & 0.18 \\
\hline $\mathrm{MgO}$ & 50.09 & 32.86 & 16.99 & 18.67 & 49.66 & 33.92 & 17.21 & 16.12 & 49.11 & 33.77 & 16.98 & 16.26 \\
\hline $\mathrm{CaO}$ & 0.04 & 0.91 & 21.67 & - & 0.04 & 0.56 & 23.07 & - & 0.05 & 0.55 & 23.18 & - \\
\hline $\mathrm{Na}_{2} \mathrm{O}$ & - & 0.05 & 0.55 & - & - & - & 0.47 & - & - & - & 0.39 & - \\
\hline $\mathrm{K}_{2} \mathrm{O}$ & - & - & - & - & - & - & - & - & - & - & - & - \\
\hline Total & 100.26 & 99.75 & 99.82 & 99.69 & 100.08 & 100.34 & 100.26 & 99.33 & 99.10 & 99.36 & 99.80 & 99.34 \\
\hline $\mathrm{Si}$ & 1.002 & 1.909 & 1.911 & 0.000 & 1.004 & 1.944 & 1.941 & 0.000 & 1.003 & 1.943 & 1.944 & 0.000 \\
\hline $\mathrm{Ti}$ & 0.000 & 0.001 & 0.003 & 0.002 & 0.000 & 0.001 & 0.003 & 0.001 & 0.001 & 0.000 & 0.002 & 0.002 \\
\hline $\mathrm{Al}$ & 0.000 & 0.160 & 0.175 & 1.496 & 0.000 & 0.106 & 0.115 & 1.211 & 0.000 & 0.108 & 0.116 & 1.222 \\
\hline $\mathrm{Cr}$ & 0.000 & 0.016 & 0.023 & 0.474 & 0.000 & 0.013 & 0.023 & 0.753 & 0.000 & 0.013 & 0.025 & 0.736 \\
\hline $\mathrm{Fe}$ & 0.177 & 0.176 & 0.088 & 0.277 & 0.184 & 0.169 & 0.064 & 0.350 & 0.185 & 0.165 & 0.062 & 0.355 \\
\hline $\mathrm{Mn}$ & 0.002 & 0.006 & 0.004 & 0.005 & 0.002 & 0.005 & 0.002 & 0.005 & 0.003 & 0.003 & 0.001 & 0.004 \\
\hline $\mathrm{Mg}$ & 1.814 & 1.698 & 0.920 & 0.759 & 1.804 & 1.736 & 0.927 & 0.695 & 1.802 & 1.743 & 0.919 & 0.700 \\
\hline $\mathrm{Ca}$ & 0.001 & 0.034 & 0.843 & 0.000 & 0.001 & 0.021 & 0.894 & 0.000 & 0.001 & 0.020 & 0.902 & 0.000 \\
\hline $\mathrm{Na}$ & 0.000 & 0.003 & 0.039 & 0.001 & 0.000 & 0.002 & 0.033 & 0.001 & 0.000 & 0.000 & 0.027 & 0.000 \\
\hline $\mathrm{K}$ & 0.000 & 0.000 & 0.000 & 0.000 & 0.000 & 0.000 & 0.000 & 0.000 & 0.000 & 0.000 & 0.000 & 0.000 \\
\hline Sum & 2.997 & 4.003 & 4.007 & 3.014 & 2.996 & 3.996 & 4.003 & 3.017 & 2.996 & 3.996 & 3.998 & 3.019 \\
\hline $\mathrm{Mg} \#$ & 91.1 & 90.6 & 91.3 & 73.3 & 90.7 & 91.1 & 93.5 & 66.5 & 90.7 & 91.4 & 93.7 & 66.4 \\
\hline Cr\# & & 9.2 & 11.7 & 24.1 & & 10.8 & 16.8 & 38.3 & & 10.6 & 17.6 & 37.6 \\
\hline
\end{tabular}

Total $\mathrm{Fe}$ as $\mathrm{FeO}^{*} ; \mathrm{Mg} \#=100 \mathrm{Mg} /(\mathrm{Mg}+\mathrm{Fe}) ; \mathrm{Cr} \#=100 \mathrm{Cr} /(\mathrm{Cr}+\mathrm{Al}) ;-$ (below the detection limits); $\mathrm{Ol}$ (olivine); Opx (orthopyroxene); Cpx (clinopyroxene); and Sp (spinel).

We estimated the equilibrium temperatures of the Baekdusan peridotites using the two-pyroxene geothermometer by Brey and Köhler [39]; this is a well-known method for calculating the solubility of the enstatite component in diopside, coexisting with orthopyroxene. We assumed a pressure of $15 \mathrm{kbar}$ for our temperature calculations because the $\mathrm{Cr}$-spinel in the peridotite can be stable at pressures of $8-25 \mathrm{kbar}[46,47]$. A pressure change of $\pm 10 \mathrm{kbar}$ would result in estimated temperature variations of only $\pm 20^{\circ} \mathrm{C}$ because the two-pyroxene geothermometer is relatively insensitive to pressure. Use of this method yielded equilibrium temperatures of $992^{\circ} \mathrm{C}$ and $845-855^{\circ} \mathrm{C}$ for the coarse- and fine-granular peridotites, respectively (Table 1 ). This range of equilibrium temperatures is consistent with the results of a previous study that also adopted the two-pyroxene geothermometer of Brey and Köhler $\left(752-997^{\circ} \mathrm{C}\right)[21]$. 


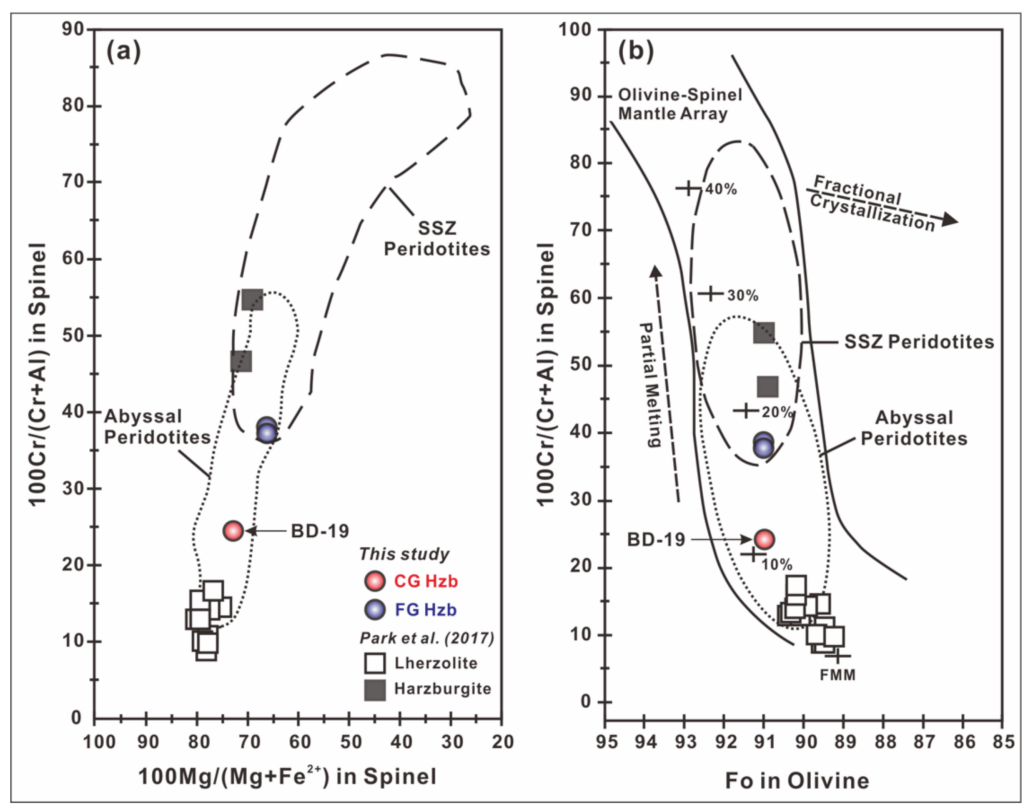

Figure 4. Plots of (a) spinel Cr\# versus Mg\# relationship and (b) olivine Fo\# versus spinel Cr\# relationship. The olivine-spinel mantle array and melting trend (annotated by melting \%) given in (b) are from Arai [48]. Data sources: abyssal peridotites [49] and suprasubduction zone (SSZ) peridotites [50-52]. FMM = fertile MORB mantle. Previous data from the Baekdusan peridotite xenoliths [21] are also shown as squares for comparison. Coarse-granular (CG; red circles) and fine-granular (FG; blue circles) harzburgite (Hzb) from the Baekdusan peridotites.

\subsection{LPOs of Minerals}

The LPO of olivine from the coarse-granular peridotite (BD-19) indicates maximum concentration of the [100] axis subparallel to the lineation, with the [010] axis strongly aligned subnormal to the foliation (Figure 5a). This is a characteristic of the A-type olivine LPO [14], indicating a dominant slip system of (010)[100]. In contrast, the LPOs of olivine from the fine-granular peridotites (BD-17 and BD-21) are characterized by a strong alignment of the [100] axis subparallel to the lineation and a weak girdle pattern for both the [010] and [001] axes subnormal to the lineation (Figure 5b,c). This is a characteristic of the D-type olivine LPO and indicates the activation of multiple slip systems of $\{0 \mathrm{kl}\}[100]$. The fabric strength of olivine (i.e., the M-index) in the Baekdusan peridotites ranges between 0.22 and 0.24 (Table 1 and Figure 5).

Generally, the fabrics of orthopyroxenes (Figure 6a-c) are much weaker than those of olivine in our samples (Figure 5). The LPOs of orthopyroxenes from both the coarse- and fine-granular peridotites exhibit alignment of the [100] axis subnormal to the foliation, whereas the [001] axis is aligned subparallel to the lineation (Figure $6 a-c$ ). This is a characteristic of the type-AC LPO of orthopyroxene [53]. The LPOs of clinopyroxenes are illustrated in Figure $6 \mathrm{~d}-\mathrm{f}$, in which the fabrics of clinopyroxenes are relatively weak. The LPOs of clinopyroxene typically indicate alignment of the [010] axis subnormal to the foliation (Figure 6d,e) and alignment of the [001] axis subparallel to the lineation (Figure $6 \mathrm{~d}-\mathrm{f}$ ). This is considered a conventional characteristic of the LPO of clinopyroxene in naturally deformed rocks $[43,44]$. The fabric strengths (i.e., M-index) of orthopyroxenes (0.04-0.07) and clinopyroxenes (0.04-0.05) are weaker than those of olivine in our samples (Figures 5 and 6). 


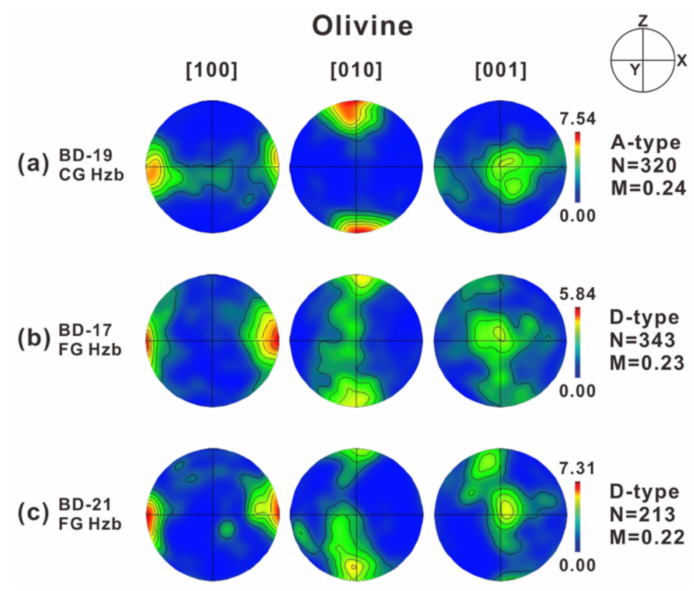

Figure 5. Pole figures showing the lattice preferred orientations (LPOs) of olivine from coarse-granular (CG) and fine-granular (FG) harzburgite (Hzb) from the Baekdusan peridotites. (a) The LPO of olivine in coarse-granular peridotite (BD-19). (b,c) The LPOs of olivine in fine-granular peridotites (BD-17, $\mathrm{BD}-21)$. The east-west direction corresponds to the stretching lineation $(\mathrm{X})$, and the north-south direction $(Z)$ is normal to the foliation. Color-coding represents the density of data points. Equal-area lower-hemisphere projection was used with a half scattering width of $20^{\circ}$. N indicates the number of grains measured. Olivine fabric (LPO) strength is denoted by M (M-index) [42].



Figure 6. Pole figures showing the lattice preferred orientations (LPOs) of $(\mathbf{a}-\mathbf{c})$ orthopyroxene and (d-f) clinopyroxene from coarse-granular (CG) and fine-granular (FG) harzburgite (Hzb) from the Baekdusan peridotites. The east-west direction corresponds to the stretching lineation $(X)$ and the north-south direction $(\mathrm{Z})$ is normal to the foliation. Color-coding represents the density of data points. Equal-area lower-hemisphere projection was used with a half scattering width of $20^{\circ}$. N indicates the number of grains measured. Pyroxene fabric (LPO) strength is denoted by M (M-index) [42].

\section{Discussion}

\subsection{The Genesis of Olivine Fabrics in the Upper Mantle}

Olivine fabrics (LPOs) developed under lithospheric conditions are well preserved in both coarseand fine-granular peridotites from the Baekdusan volcano (Figure 5). Our peridotite samples exhibit intracrystalline deformation microstructures such as subgrain boundaries and undulose extinctions in olivine (Figure 3). Together, these deformation microstructures and LPO patterns imply that the Baekdusan peridotites were deformed by a dislocation creep regime.

We found the olivine LPO patterns to vary depending on the sample texture. For the coarse-granular peridotite, the olivine LPO exhibited alignment of the [100] axes subparallel to the lineation and a strong alignment of the [010] axis subnormal to the foliation (Figure 5a); this is a characteristic of the A-type olivine LPO. Previously, the A-type olivine LPOs have been observed under conditions of high 
temperature, low water content, and low stress, both in experimental studies investigating the plastic deformation of olivine [14,54-57] and in naturally deformed peridotites [12,58-61]. Application of the two-pyroxene geothermometer to the coarse-granular peridotite from the Baekdusan volcano produced a high estimate of equilibrium temperature (approximately $990^{\circ} \mathrm{C}$ ) (Table 1), and the stress of this sample was estimated to be low (9 MPa, Table 1). Therefore, we consider the A-type LPO of olivine in the coarse-granular peridotite to have been preserved from the original olivine fabric formed under high-temperature (approximately $1000^{\circ} \mathrm{C}$ ), low-stress, and dry conditions.

The olivine LPOs for our fine-granular peridotites exhibit a strong alignment of the [100] axes subparallel to the lineation and a weak girdle pattern for both the [010] and [001] axes subnormal to the lineation (Figure $5 b, c)$. This is a characteristic of the D-type olivine LPO. Previously, the D-type olivine LPOs have been observed primarily at low temperature and high stress regions in lithospheric shear zones [61-66]. Previous experimental studies, natural observations, and numerical modeling suggest that the D-type olivine LPOs may be formed by the following: (i) activation of multiple $\{0 \mathrm{kl}\}[100]$ slip systems under higher stress conditions than those forming the A-type olivine LPOs $[16,55,67]$; (ii) activation of only the (010)[100] slip system under transtensional deformation regimes [68]; (iii) activation of dominant (010)[100] and (001)[100] slip systems under high-temperature and low-stress conditions, with strain compatibility constraints relaxed by grain-to-grain interactions (numerical simulations) [69]; or (iv) dislocation-accommodated grain boundary sliding (DisGBS) [56,63] under moderate transient strain conditions [70]. The equilibrium temperature we have obtained for the fine-granular peridotites from the Baekdusan volcano is lower $\left(845-855^{\circ} \mathrm{C}\right)$ than that obtained for the coarse-granular peridotite (Table 1). Moreover, the stress estimates obtained using a recrystallized grain size piezometer [45] indicate that stress in the fine-granular peridotites is relatively high (14-16 $\mathrm{MPa})$ compared to that in the coarse-granular peridotite (9 MPa) (Table 1). If the D-type LPO of olivine was formed by the transtensional deformation regime as in case (ii), the LPOs of orthopyroxene and clinopyroxene would exhibit similar characteristics, i.e., the girdle distribution observed for the [010] and [001] axes, because the LPOs of pyroxenes and olivine typically form against the same structural background [71,72]. Furthermore, the mechanisms required for the formation of D-type olivine fabrics in cases (iii) to (iv) are typically related to high temperatures $\left(1200^{\circ} \mathrm{C}\right)$, and thus cases from (ii) to (iv) must be rejected. Consequently, we consider the D-type LPO of olivine in the fine-granular peridotites from the Baekdusan volcano to have been formed under lower temperature (approximately $850{ }^{\circ} \mathrm{C}$ ), slightly higher stress, and dry conditions at shallower depth, comparing to the A-type LPO of olivine.

\subsection{Petrogenesis and Evolution of Deformation Fabrics of the Baekdusan Peridotites}

The lack of a reliable geobarometer for the spinel peridotite stability field makes it very difficult to estimate extraction depths (or equilibrium pressure) for the spinel peridotite xenoliths. However, the extraction depths (or equilibrium pressure) of xenoliths can often be estimated by plotting their equilibrium temperatures on a geotherm derived from surface heat flow data, because heat flow is a key parameter used to constrain lithospheric thermal structures [73]. Thus, we estimated the extraction depths (or equilibrium pressures) of the Baekdusan peridotite xenoliths (Figure 7) by plotting their equilibrium temperatures $\left(\mathrm{T}_{\text {Two-Pyx }}\right.$; two-pyroxene geothermometer; Table 1 ) on the geotherm of the Bohai Bay Basin in the NCC [74]; this is one of the few available datasets in the vicinity of the Baekdusan volcano. For the coarse-granular $\left(\mathrm{T}_{\mathrm{Two}-\mathrm{Pyx}}: 992^{\circ} \mathrm{C}\right)$ and fine-granular $\left(\mathrm{T}_{\mathrm{Two}-\mathrm{Pyx}}: 845-855^{\circ} \mathrm{C}\right)$ peridotites, we obtained extraction depth ranges of approximately $50-55 \mathrm{~km}$ and $40-45 \mathrm{~km}$, respectively (Figure 7). These results are consistent with the depth ranges obtained for the Moho (30-35 km) and lithosphere-asthenosphere boundary $(50-70 \mathrm{~km})$ in a previous geophysical study [75] and with the spinel-garnet phase transformation boundary [76] as shown in Figure 7. Such consistent variation in equilibrium temperature with the sample texture may indicate that the Baekdusan peridotite xenoliths were derived from a compositionally and texturally heterogeneous vertical mantle section beneath the Baekdusan volcano. However, additional petrochemical and microstructural data relating to the Baekdusan peridotite xenoliths will be required to validate this hypothesis. 


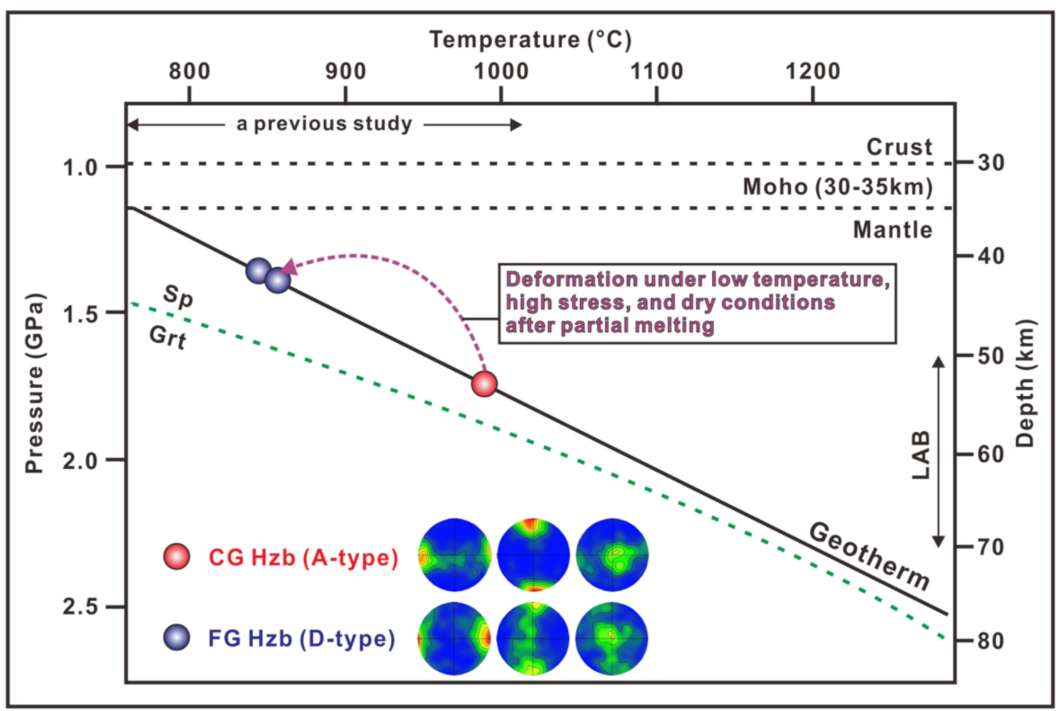

Figure 7. A summary figure showing the relationship between olivine fabrics and deformation conditions in the Baekdusan peridotites. The equilibrium temperatures are projected onto the geotherm (solid line) of the Bohai Bay Basin in the NCC [74]. The spinel (Sp)-garnet (Grt) phase transformation (green dashed line) is from O'Reilly and Griffin [76]. The crust-mantle boundary (Moho) depth (30-35 km; black dashed lines) and lithosphere-asthenosphere boundary (LAB) depth (50-70 km) beneath the Baekdusan volcano are from Kim et al. [75]. The equilibrium temperature range indicated by previous data from the Baekdusan peridotite xenoliths is also shown [21]. Coarse-granular (CG) and fine-granular (FG) harzburgite (Hzb). Representative A-type and D-type LPOs of olivine from BD-19 and BD-17, respectively.

In general, the relationship between the olivine Fo content (Mg\#) and spinel Cr\# of peridotites is an excellent indicator of the extent of melt extraction from mantle rocks $[48,49,77]$. Both the olivine Fo content and spinel $\mathrm{Cr} \#$ increase with increasing degree of partial melting in the peridotite samples studied here (Figure 4b). The major element mineral chemistry (Table 2) and olivine-spinel compositional relationships (Figure $4 \mathrm{~b}$ ) obtained here indicate that the Baekdusan peridotites (i.e., harzburgites) are residues that have experienced partial melting (ca. $<10 \%$ and $<20 \%$ for the coarse-granular and fine-granular harzburgites, respectively). This result is broadly consistent with the degree of partial melting (ca. $\leq 25 \%$ ) estimated in a previous geochemical study [21]. Based on petrographic and microstructural observations, we found intracrystalline deformation features such as subgrains, undulose extinctions, and strong olivine LPOs in the fine-granular harzburgites, although these have experienced a high degree of partial melting (ca. $<20 \%$ ). This explains the relatively weak fabric strength (M-index) observed for the LPOs of clinopyroxene and orthopyroxene compared to olivine (Figures 5 and 6). If a high degree of partial melting had occurred in the fine-granular harzburgites after the main deformation events, the recorded intracrystalline deformation microstructures observed in the present study would have been destroyed by annealing (recovery) processes (e.g., grain growth) under relatively high-temperature conditions during the partial melting process. In contrast, the A-type olivine LPO has been preserved in the coarse-granular peridotite owing to the relatively small degree of partial melting (ca. $<10 \%$ ). In summary, we infer that a high degree of partial melting occurred in the fine-granular harzburgites before the main deformation event; this resulted in intracrystalline deformation microstructures, forming the D-type olivine LPO under low-temperature, high-stress, and dry conditions (Figure 7). The A-type olivine LPO observed in the coarse-granular peridotite may be related to the preexisting Archean cratonic mantle fabric (i.e., old frozen LPO) that formed under high-temperature and low-stress conditions in a deeper section (50-55 km), whereas the D-type olivine LPO in the fine-granular peridotites likely originated from later localized deformation events under low-temperature and high-stress conditions in a shallower section $(40-45 \mathrm{~km})$ after a high degree of partial melting. However, a more precise interpretation of the tectonic 
history of our study area will require more data regarding the microstructures and geochemistry of these lithologies.

\section{Conclusions}

We report, for the first time, the deformation microstructures and lattice preferred orientations (LPOs) of minerals alongside petrological data from spinel peridotite xenoliths beneath the Baekdusan volcano. Based on petrographic features and deformation microstructures, we have identified two categories of peridotites: coarse- and fine-granular harzburgites. The olivine LPO in the coarse-granular peridotite exhibits a maximum concentration of [100] axes subparallel to the lineation, whereas the [010] axes are aligned strongly subnormal to the foliation (A-type olivine LPO). In contrast, the olivine LPOs in the fine-granular peridotites exhibit a strong alignment of the [100] axes subparallel to the lineation and a weak girdle pattern for both the [010] and [001] axes subnormal to the lineation (D-type olivine LPO). We found that mineral composition, equilibrium temperature, stress, and extraction depth vary considerably with the sample texture. Based on these differences, we infer that the A-type olivine LPO of the coarse-granular peridotite reflects the preexisting Archean cratonic mantle fabric (i.e., old frozen LPO) formed under high-temperature (approximately $990^{\circ} \mathrm{C}$ ), low-stress, and dry conditions in a deep section (50-55 km). Conversely, we infer that the D-type olivine LPO of the fine-granular peridotites likely originated from a later localized deformation event under low-temperature (approximately $\left.850^{\circ} \mathrm{C}\right)$, high-stress, and dry conditions in a shallow section $(40-45 \mathrm{~km}$ ) after a high degree of partial melting (ca. $<20 \%$ ). We propose that the Baekdusan peridotite xenoliths were derived from a compositionally and texturally heterogeneous vertical mantle section beneath the Baekdusan volcano.

Author Contributions: Conceptualization, M.P. and Y.K.; methodology, M.P. and H.J.; software, M.P.; validation, M.P., H.J., and Y.K.; formal analysis, M.P.; investigation, M.P.; resources, Y.K. and H.J.; data curation, M.P.; writing-original draft preparation, M.P.; writing-review and editing, Y.K. and H.J.; visualization, M.P.; supervision, H.J.; project administration, H.J.; and funding acquisition, M.P., Y.K., and H.J. All authors have read and agreed to the published version of the manuscript.

Funding: This study was supported by the National Research Foundation of Korea (NRF: 2018R1D1A3B07048228 to Y.K., NRF: 2017R1A2B2004688, 2020R1A2C2003765 to H.J. and NRF: 2019R1C1C1004402 to M.P.).

Acknowledgments: The authors would like to thank Hwayoung Kim (Korea Polar Research Institute) for the EPMA analyses. The authors are grateful to the Editor and two anonymous reviewers, whose suggestions and comments have notably improved the manuscript.

Conflicts of Interest: The authors declare no conflict of interest.

\section{References}

1. Bascou, J.; Doucet, L.S.; Saumet, S.; Ionov, D.A.; Ashchepkov, I.V.; Golovin, A.V. Seismic velocities, anisotropy and deformation in Siberian cratonic mantle: EBSD data on xenoliths from the Udachnaya kimberlite. Earth Planet. Sci. Lett. 2011, 304, 71-84. [CrossRef]

2. Wu, F.-Y.; Yang, J.-H.; Xu, Y.-G.; Wilde, S.A.; Walker, R.J. Destruction of the North China Craton in the Mesozoic. Annu. Rev. Earth Planet. Sci. 2019, 47, 173-195. [CrossRef]

3. Liu, J.; Cai, R.; Pearson, D.G.; Scott, J.M. Thinning and destruction of the lithospheric mantle root beneath the North China Craton: A review. Earth Sci. Rev. 2019, 196, 102873. [CrossRef]

4. Tang, Y.-J.; Zhang, H.-F.; Ying, J.-F.; Su, B.-X. Widespread refertilization of cratonic and circum-cratonic lithospheric mantle. Earth Sci. Rev. 2013, 118, 45-68. [CrossRef]

5. Frey, F.A.; Green, D.H. The mineralogy, geochemistry and origin of Iherzolite inclusions in Victorian basanites. Geochim. Cosmochim. Acta 1974, 38, 1023-1059. [CrossRef]

6. Jordan, T.H. The continental tectosphere. Rev. Geophys. 1975, 13, 1-12. [CrossRef]

7. King, S.D. Archean cratons and mantle dynamics. Earth Planet. Sci. Lett. 2005, 234, 1-14. [CrossRef]

8. Griffin, W.L.; O'Reilly, S.Y.; Afonso, J.C.; Begg, G.C. The Composition and Evolution of Lithospheric Mantle: A Re-evaluation and its Tectonic Implications. J. Petrol. 2009, 50, 1185-1204. [CrossRef]

9. Mercier, J.-C.C.; Nicolas, A. Textures and fabrics of upper-mantle peridotites as illustrated by xenoliths from basalts. J. Petrol. 1975, 16, 454-487. [CrossRef] 
10. Jung, H. Crystal preferred orientations of olivine, orthopyroxene, serpentine, chlorite, and amphibole, and implications for seismic anisotropy in subduction zones: A review. Geosci. J. 2017, 21, 985-1011. [CrossRef]

11. Park, M.; Berkesi, M.; Jung, H.; Kil, Y. Fluid infiltration in the lithospheric mantle beneath the Rio Grande Rift, USA: A fluid-inclusion study. Eur. J. Mineral. 2017. [CrossRef]

12. Park, M.; Jung, H.; Kil, Y. Petrofabrics of olivine in a rift axis and rift shoulder and their implications for seismic anisotropy beneath the Rio Grande rift. Isl. Arc 2014, 23, 299-311. [CrossRef]

13. Park, Y.; Jung, H. Deformation microstructures of olivine and pyroxene in mantle xenoliths in Shanwang, eastern China, near the convergent plate margin, and implications for seismic anisotropy. Int. Geol. Rev. 2015, 57, 629-649. [CrossRef]

14. Jung, H.; Karato, S. Water-induced fabric transitions in olivine. Science 2001, 293, 1460-1463. [CrossRef] [PubMed]

15. Katayama, I.; Jung, H.; Karato, S.I. New type of olivine fabric from deformation experiments at modest water content and low stress. Geology 2004, 32, 1045-1048. [CrossRef]

16. Jung, H.; Katayama, I.; Jiang, Z.; Hiraga, I.; Karato, S. Effect of water and stress on the lattice-preferred orientation of olivine. Tectonophysics 2006, 421, 1-22. [CrossRef]

17. Katayama, I.; Karato, S. Effect of temperature on the B- to C-type olivine fabric transition and implication for flow pattern in subduction zones. Phys. Earth Planet. Inter. 2006, 157, 33-45. [CrossRef]

18. Mainprice, D.; Tommasi, A.; Couvy, H.; Cordier, P.; Frost, D.J. Pressure sensitivity of olivine slip systems and seismic anisotropy of Earth's upper mantle. Nature 2005, 433, 731-733. [CrossRef]

19. Jung, H.; Mo, W.; Green, H.W. Upper mantle seismic anisotropy resulting from pressure-induced slip transition in olivine. Nat. Geosci. 2009, 2, 73-77. [CrossRef]

20. Ohuchi, T.; Kawazoe, T.; Nishihara, Y.; Nishiyama, N.; Irifune, T. High pressure and temperature fabric transitions in olivine and variations in upper mantle seismic anisotropy. Earth Planet. Sci. Lett. 2011, 304, 55-63. [CrossRef]

21. Park, K.; Choi, S.H.; Cho, M.; Lee, D.-C. Evolution of the lithospheric mantle beneath Mt. Baekdu (Changbaishan): Constraints from geochemical and Sr-Nd-Hf isotopic studies on peridotite xenoliths in trachybasalt. Lithos 2017, 286-287, 330-344. [CrossRef]

22. Choi, H.-O.; Choi, S.H.; Lee, Y.S.; Ryu, J.-S.; Lee, D.-C.; Lee, S.-G.; Sohn, Y.K.; Liu, J.-Q. Petrogenesis and mantle source characteristics of the late Cenozoic Baekdusan (Changbaishan) basalts, North China Craton. Gondwana Res. 2020, 78, 156-171. [CrossRef]

23. Wu, F.-Y.; Walker, R.J.; Ren, X.-W.; Sun, D.-Y.; Zhou, X.-H. Osmium isotopic constraints on the age of lithospheric mantle beneath northeastern China. Chem. Geol. 2003, 196, 107-129. [CrossRef]

24. Kuritani, T.; Kimura, J.-I.; Ohtani, E.; Miyamoto, H.; Furuyama, K. Transition zone origin of potassic basalts from Wudalianchi volcano, northeast China. Lithos 2013, 156-159, 1-12. [CrossRef]

25. Liu, D.Y.; Nutman, A.P.; Compston, W.; Wu, J.S.; Shen, Q.H. Remnants of $\geq 3800$ Ma crust in the Chinese part of the Sino-Korean craton. Geology 1992, 20, 339-342. [CrossRef]

26. Liu, D.; Wilde, S.A.; Wan, Y.; Wu, J.; Zhou, H.; Dong, C.; Yin, X. New U-Pb and Hf isotopic data confirm Anshan as the oldest preserved segment of the North China Craton. Am. J. Sci. 2008, 308, 200-231. [CrossRef]

27. Zhao, G.; Wilde, S.A.; Cawood, P.A.; Sun, M. Archean blocks and their boundaries in the North China Craton: Lithological, geochemical, structural and P-T path constraints and tectonic evolution. Precambrian Res. 2001, 107, 45-73. [CrossRef]

28. Yang, J.-H.; Wu, F.-Y.; Wilde, S.A.; Belousova, E.; Griffin, W.L. Mesozoic decratonization of the North China block. Geology 2008, 36, 467-470. [CrossRef]

29. Wu, F.-Y.; Lin, J.-Q.; Wilde, S.A.; Zhang, X.O.; Yang, J.-H. Nature and significance of the Early Cretaceous giant igneous event in eastern China. Earth Planet. Sci. Lett. 2005, 233, 103-119. [CrossRef]

30. Wu, F.-Y.; Yang, J.-H.; Wilde, S.A.; Zhang, X.-O. Geochronology, petrogenesis and tectonic implications of Jurassic granites in the Liaodong Peninsula, NE China. Chem. Geol. 2005, 221, 127-156. [CrossRef]

31. Zou, H.; Zindler, A.; Xu, X.; Qi, Q. Major, trace element, and Nd, Sr and Pb isotope studies of Cenozoic basalts in SE China: Mantle sources, regional variations, and tectonic significance. Chem. Geol. 2000, 171, 33-47. [CrossRef]

32. Cheong, A.C.-S.; Jeong, Y.-J.; Jo, H.J.; Sohn, Y.K. Recurrent Quaternary magma generation at Baekdusan (Changbaishan) volcano: New zircon U-Th ages and Hf isotopic constraints from the Millennium Eruption. Gondwana Res. 2019, 68, 13-21. [CrossRef] 
33. Zhao, D.; Tian, Y.; Lei, J.; Liu, L.; Zheng, S. Seismic image and origin of the Changbai intraplate volcano in East Asia: Role of big mantle wedge above the stagnant Pacific slab. Phys. Earth Planet. Inter. 2009, 173, 197-206. [CrossRef]

34. Tang, Y.; Obayashi, M.; Niu, F.; Grand, S.P.; Chen, Y.J.; Kawakatsu, H.; Tanaka, S.; Ning, J.; Ni, J.F. Changbaishan volcanism in northeast China linked to subduction-induced mantle upwelling. Nat. Geosci. 2014, 7, 470-475. [CrossRef]

35. Kuritani, T.; Xia, Q.-K.; Kimura, J.-I.; Liu, J.; Shimizu, K.; Ushikubo, T.; Zhao, D.; Nakagawa, M.; Yoshimura, S. Buoyant hydrous mantle plume from the mantle transition zone. Sci. Rep. 2019, 9, 6549. [CrossRef]

36. Wei, H.; Liu, G.; Gill, J. Review of eruptive activity at Tianchi volcano, Changbaishan, northeast China: Implications for possible future eruptions. Bull. Volcanol. 2013, 75, 706. [CrossRef]

37. Wei, H.; Sparks, R.S.J.; Liu, R.; Fan, Q.; Wang, Y.; Hong, H.; Zhang, H.; Chen, H.; Jiang, C.; Dong, J.; et al. Three active volcanoes in China and their hazards. J. Asian Earth Sci. 2003, 21, 515-526. [CrossRef]

38. Wei, H.; Wang, Y.; Jin, J.; Gao, L.; Yun, S.-H.; Jin, B. Timescale and evolution of the intracontinental Tianchi volcanic shield and ignimbrite-forming eruption, Changbaishan, Northeast China. Lithos 2007, 96, 315-324. [CrossRef]

39. Brey, G.P.; Köhler, T. Geothermobarometry in four-phase lherzolites II. New thermobarometers, and practical assessment of existing thermobarometers. J. Petrol. 1990, 31, 1353-1378. [CrossRef]

40. Park, M.; Jung, H. Relationships between eclogite-facies mineral assemblages, deformation microstructures, and seismic properties in the Yuka Terrane, North Qaidam Ultrahigh-Pressure Metamorphic Belt, NW China. J. Geophys. Res. Solid Earth 2019, 124, 13168-13191. [CrossRef]

41. Park, M.; Jung, H. Analysis of electron backscattered diffraction (EBSD) mapping of geological materials: Precautions for reliably collecting and interpreting data on petro-fabric and seismic anisotropy. Geosci. J. 2020. [CrossRef]

42. Skemer, P.; Katayama, I.; Jiang, Z.; Karato, S.-I. The misorientation index: Development of a new method for calculating the strength of lattice-preferred orientation. Tectonophysics 2005, 411, 157-167. [CrossRef]

43. Amiguet, E.; Raterron, P.; Cordier, P.; Couvy, H.; Chen, J.C. Deformation of diopside single crystal at mantle pressure 1: Mechanical data. Phys. Earth Planet. Inter. 2009, 177, 122-129. [CrossRef]

44. Helmstaedt, H.; Anderson, O.L.; Gavasci, A.T. Petrofabric studies of eclogite, spinel-Websterite, and spinel-lherzolite Xenoliths from kimberlite-bearing breccia pipes in southeastern Utah and northeastern Arizona. J. Geophys. Res. 1972, 77, 4350-4365. [CrossRef]

45. Van der Wal, D.; Chopra, P.; Drury, M.; Gerald, J.F. Relationships between dynamically recrystallized grain size and deformation conditions in experimentally deformed olivine rocks. Geophys. Res. Lett. 1993, 20, 1479-1482. [CrossRef]

46. Nickel, K.G. Phase equilibria in the system $\mathrm{SiO}_{2}-\mathrm{MgO}-\mathrm{Al}_{2} \mathrm{O}_{3}-\mathrm{CaO}-\mathrm{Cr}_{2} \mathrm{O}_{3}$ (SMACCR) and their bearing on spinel/garnet lherzolite relationships. Neues Jahrb. Mineral. Abh. 1986, 155, 259-287.

47. Webb, S.A.C.; Wood, B.J. Spinel-pyroxene-garnet relationships and their dependence on $\mathrm{Cr} / \mathrm{Al}$ ratio. Contrib. Mineral. Petrol. 1986, 92, 471-480. [CrossRef]

48. Arai, S. Characterization of spinel peridotites by olivine-spinel compositional relationships: Review and interpretation. Chem. Geol. 1994, 113, 191-204. [CrossRef]

49. Dick, H.J.B.; Bullen, T. Chromian spinel as a petrogenetic indicator in abyssal and alpine-type peridotites and spatially associated lavas. Contrib. Mineral. Petrol. 1984, 86, 54-76. [CrossRef]

50. Ishii, T.; Robinson, P.T.; Maekawa, H.; Fiske, R. Petrological studies of peridotites from diapiric serpentinite seamounts in the Izu-Ogasawara-Mariana forearc, Leg 125. Proc. Ocean. Drill. Program Sci. Results 1992, 125, 445-485.

51. Parkinson, I.J.; Pearce, J.A. Peridotites from the Izu-Bonin-Mariana Forearc (ODP Leg 125): Evidence for Mantle Melting and Melt-Mantle Interaction in a Supra-Subduction Zone Setting. J. Petrol. 1998, 39, 1577-1618. [CrossRef]

52. Pearce, J.A.; Barker, P.F.; Edwards, S.J.; Parkinson, I.J.; Leat, P.T. Geochemistry and tectonic significance of peridotites from the South Sandwich arc-basin system, South Atlantic. Contrib. Mineral. Petrol. 2000, 139, 36-53. [CrossRef]

53. Jung, H.; Park, M.; Jung, S.; Lee, J. Lattice preferred orientation, water content, and seismic anisotropy of orthopyroxene. J. Earth Sci. 2010, 21, 555-568. [CrossRef] 
54. Zhang, S.; Karato, S.-I. Lattice preferred orientation of olivine aggregates deformed in simple shear. Nature 1995, 375, 774-777. [CrossRef]

55. Zhang, S.; Karato, S.-I.; Fitz Gerald, J.; Faul, U.H.; Zhou, Y. Simple shear deformation of olivine aggregates. Tectonophysics 2000, 316, 133-152. [CrossRef]

56. Hansen, L.N.; Zimmerman, M.E.; Kohlstedt, D.L. The influence of microstructure on deformation of olivine in the grain-boundary sliding regime. J. Geophys. Res. Solid Earth 2012, 117, B09201. [CrossRef]

57. Karato, S.; Jung, H.; Katayama, I.; Skemer, P. Geodynamic significance of seismic anisotropy of the upper mantle: New insights from laboratory studies. Annu. Rev. Earth Planet. Sci. 2008, 36, 59-95. [CrossRef]

58. Michibayashi, K.; Mainprice, D. The Role of Pre-existing Mechanical Anisotropy on Shear Zone Development within Oceanic Mantle Lithosphere: An Example from the Oman Ophiolite. J. Petrol. 2004, 45, 405-414. [CrossRef]

59. Jung, H.; Mo, W.; Choi, S.H. Deformation microstructures of olivine in peridotite from Spitsbergen, Svalbard and implications for seismic anisotropy. J. Metamorph. Geol. 2009, 27, 707-720. [CrossRef]

60. Falus, G.; Tommasi, A.; Soustelle, V. The effect of dynamic recrystallization on olivine crystal preferred orientations in mantle xenoliths deformed under varied stress conditions. J. Struct. Geol. 2011, 33, 1528-1540. [CrossRef]

61. Park, M.; Jung, H. Microstructural evolution of the Yugu peridotites in the Gyeonggi Massif, Korea: Implications for olivine fabric transition in mantle shear zones. Tectonophysics 2017, 709, 55-68. [CrossRef]

62. Skemer, P.; Warren, J.M.; Kelemen, P.B.; Hirth, G. Microstructural and Rheological Evolution of a Mantle Shear Zone. J. Petrol. 2010, 51, 43-53. [CrossRef]

63. Warren, J.M.; Hirth, G.; Kelemen, P.B. Evolution of olivine lattice preferred orientation during simple shear in the mantle. Earth Planet. Sci. Lett. 2008, 272, 501-512. [CrossRef]

64. Linckens, J.; Herwegh, M.; Muntener, O. Linking temperature estimates and microstructures in deformed polymineralic mantle rocks. Geochem. Geophys. Geosyst. 2011, 12. [CrossRef]

65. Linckens, J.; Herwegh, M.; Muntener, O.; Mercolli, I. Evolution of a polymineralic mantle shear zone and the role of second phases in the localization of deformation. J. Geophys. Res. Solid Earth 2011, 116. [CrossRef]

66. Kaczmarek, M.-A.; Jonda, L.; Davies, H.L. Evidence of melting, melt percolation and deformation in a supra-subduction zone (Marum ophiolite complex, Papua New Guinea). Contrib. Mineral. Petrol. 2015, 170, 1-23. [CrossRef]

67. Bystricky, M.; Kunze, K.; Burlini, L.; Burg, J.-P. High Shear Strain of Olivine Aggregates: Rheological and Seismic Consequences. Science 2000, 290, 1564-1567. [CrossRef]

68. Tommasi, A.; Tikoff, B.; Vauchez, A. Upper mantle tectonics: Three-dimensional deformation, olivine crystallographic fabrics and seismic properties. Earth Planet. Sci. Lett. 1999, 168, 173-186. [CrossRef]

69. Tommasi, A.; Mainprice, D.; Canova, G.; Chastel, Y. Viscoplastic self-consistent and equilibrium-based modeling of olivine lattice preferred orientations: Implications for the upper mantle seismic anisotropy. J. Geophys. Res. Solid Earth 2000, 105, 7893-7908. [CrossRef]

70. Hansen, L.N.; Zhao, Y.-H.; Zimmerman, M.E.; Kohlstedt, D.L. Protracted fabric evolution in olivine: Implications for the relationship among strain, crystallographic fabric, and seismic anisotropy. Earth Planet. Sci. Lett. 2014, 387, 157-168. [CrossRef]

71. Higgie, K.; Tommasi, A. Deformation in a partially molten mantle: Constraints from plagioclase lherzolites from Lanzo, western Alps. Tectonophysics 2014, 615-616, 167-181. [CrossRef]

72. Yang, Y.; Abart, R.; Yang, X.; Shang, Y.; Ntaflos, T.; Xu, B. Seismic anisotropy in the Tibetan lithosphere inferred from mantle xenoliths. Earth Planet. Sci. Lett. 2019, 515, 260-270. [CrossRef]

73. Balling, N. Heat flow and thermal structure of the lithosphere across the Baltic Shield and northern Tornquist Zone. Tectonophysics 1995, 244, 13-50. [CrossRef]

74. Jiang, G.; Hu, S.; Shi, Y.; Zhang, C.; Wang, Z.; Hu, D. Terrestrial heat flow of continental China: Updated dataset and tectonic implications. Tectonophysics 2019, 753, 36-48. [CrossRef]

75. Kim, S.; Tkalčić, H.; Rhie, J. Seismic constraints on magma evolution beneath Mount Baekdu (Changbai) volcano from transdimensional Bayesian inversion of ambient noise data. J. Geophys. Res. Solid Earth 2017, 122, 5452-5473. [CrossRef]

76. O’Reilly, S.Y.; Griffin, W.L. 4-D Lithosphere Mapping: Methodology and examples. Tectonophysics 1996, 262, 3-18. [CrossRef] 
77. Hellebrand, E.; Snow, J.E.; Dick, H.J.B.; Hofmann, A.W. Coupled major and trace elements as indicators of the extent of melting in mid-ocean-ridge peridotites. Nature 2001, 410, 677-681. [CrossRef]

(C) 2020 by the authors. Licensee MDPI, Basel, Switzerland. This article is an open access article distributed under the terms and conditions of the Creative Commons Attribution (CC BY) license (http://creativecommons.org/licenses/by/4.0/). 